\title{
An Impact Study of Hymnody on Selected Ghanaian Churches
}

\author{
Edwin Boateng Afriyie ${ }^{1}$ \\ 1 Department of Theology, Christ Apostolic University College, Kumasi, Ghana.
}

\begin{abstract}
This paper is an investigation of the efficacy of hymns and their impact on personality. The investigation was aimed at addressing 'the problem of the relationship of hymnody and discipline, self-regulation which results in guarded behaviour reflecting in speech, personal appearance, and conduct within the Ghanaian society.' The investigation was against the backdrop of the perception that hymnody influences devoted singers with the power to shape personality and bring about character transformation. The objective of the investigation was to spike the hymnody effect within society. The theory of personal transformation combined the qualitative design. The study consisted of a single question to determine the most predominant view about hymnody in hymn-singing churches in Accra and Kumasi. Findings indicated that $41 \%$ of 300 informants confirmed hymnody as powerful and transformative, but elitist and excluded the non-literate. Eurocentric and Afrocentric perspectives attended the analysis of Hymnody. The study concluded that hymnody is beneficial to mood and character change to stimulate the transformation of soul and mind, leading to the growth of the inner man as a function of discipline. Thus, a reference to the notions of pedagogy and discipline are underscored as transforming outcomes of devoted hymnody participation. The paper's contribution to knowledge lies in its focus on the role of hymnody, a religious ritual, as catalyzing the development of the discipline ethic to engage the attention of the academy for further research.
\end{abstract}

Keywords: Discipline, Ghana, Hymnody, Personality.

\section{INTRODUCTION}

Hymnody is the singing or composition of hymns or sacred songs; it is the sense in which the word is applied in this paper. As a practice within the church community, it is perceived to be powerful for character transformation to improve personality. The perception has necessitated the problem of the relationship of hymnody and discipline, self-regulation which results in guarded behaviour reflecting in speech, personal appearance, and conduct within Ghanaian society. Consequently, the discipline ethic and religious practice were implicated in the investigation of the paper. To provide enriching knowledge about hymnody, some additional but useful information has been provided on hymn sources, historical development, utility, and form. Also, information on the significance of hymns and the retail of the same in Ghana have been discussed. Richard Tedeschi and Lawrence Calhoun's ${ }^{1}$ theory of personal transformation frame a methodology

\footnotetext{
Richard, G, Tedeschi and Lawrence, G., Calhoun, "Pathways to Personal Transformation: Theoretical and Empirical Developments," In: P. T. P. Wong (Ed.), Personality and Clinical Psychology Series. The Human Quest For Meaning: Theories, Research, and Applications (Routledge/Taylor \& Francis Group, 2012), 559-572.
} 
for the study. The theory of personal transformation suggests that "transformation can be set in motion by intensely affective experiences that lead to revisions in the way individuals think of themselves, their world, the future, and their place in it, human nature, good, and a variety of other matters." 2 The theory reckons a mental reflection of exacting emotions of life experiences as triggering the personal transformation. By implication, the theory assumes diverse assumptions, beliefs, and resolutions as the objects of personality change. These objects as the focal elements of change are affected at different times, momentarily or over time it would seem, to compel narrative change that results in personal transformation.

Thus, the theory concedes the change of narratives as mediating experiences that may be positive or negative, spiritual or otherwise. Such compelling narrative changes include religious encounters that channel hymnody or song.

Informants were used in the study since insider knowledge and experience of hymnody would provide authoritative voices. They were drawn from noted hymnody churches in Accra and Kumasi including the Anglican, Presbyterian, Methodist, Assemblies of God, Baptist, and the Roman Catholic Churches of Ghana. The demographic participation was 50\% male and 50\% female between the ages of eighteen and seventy years. Literate informants were used due to the English language content of classical hymnody. Data was analyzed based on a five-point answer option as found in the survey analyses table on page 12 of the paper.

\section{Background}

Historically, songs with similarity to hymns and categorized as such, are known to have existed across civilizations from ancient times. Examples of such songs branded as hymns have continued from the ancient Sumerian and Greek cultures. It is no coincidence that the term hymn takes its root from hymnos, a Greek word meaning 'song of praise,' a hymn is sung to God and sometimes to a saint or a nation in the Christian tradition. ${ }^{3}$

Hymnody has been a traditional part of the worship of the Jews with evidence since the time of Moses. In the celebration of the Passover with the Disciples, after the Last Supper, Jesus and the Disciples sung hymns. This was done in line with the tradition of the Passover celebration. It is conjectured that the hymn sung by Jesus with the Disciples on this faithful occasion was drawn from Psalms 115 - 118 .

Hymnody gradually evolved but this process took an accelerated turn with the legalization of Christianity by Emperor Constantine (313 CE). Thereafter, it blossomed first in Syria, where the Gnostics and Manichaeans mimicked the practice using the psalms. In the Byzantine church, the assimilation of hymnody into its liturgy maintained more prominence than in the Latin liturgy. The Byzantine church developed two complex types of hymnody. The first was the kontakion (credited to Romanos Melodos), apparently in the $6^{\text {th }}$ Cent., and official usage of the term by the $9^{\text {th }}$ Cent. The second type was the $k \bar{a} n o n$ which gained prominence in the late $7^{\text {th }}$ and $8^{\text {th }}$ Cents. ${ }^{4}$

Kontakion denoted a scroll and a stick around which was wound long scrolls with textual cover. In form, it was a poetic homily of 18 - 30 stanzas. In terms of its singing, it was rendered as a chant on the same pattern, as the first stanza and joined by a common refrain sung by a choir and the stanzas by a soloist. The picture from this was a choir rendition of a two-part activity but jointly undertaken, nonetheless in turns, by a choir and its solo singer. Thus, hymnody at this point was an exclusive activity of choir groups. ${ }^{5}$

Kanon was made of nines odes and derived from biblical canticles mostly found in the Old Testament. The final part of the ode is taken from the Magnificat, Song of Zachariah, and the New Testament. It replaced the kontakion over time. Characteristically, each kanon focuses on a specific theme for example repentance, peace, or honoring a particular saint. Often more than one kanon was chanted together. ${ }^{6}$

\section{Source}

Scripture is the source of biblical hymns as has been observed that what Jesus and the Disciples sung were

\footnotetext{
Tedeschi, and Calhoun, Pathways to Personal Transformation, 559-572.

Britannica Academic, "Hymn" accessed January 3, 2021,

https://www.academic-ec.com.eres.qnl.qa/levels.collegiate/article/hymn/41781

4 Britannica Academic, "Hymn."

Britannica Academic, "Hymn."

6 Religious Music in the West, “Kontakion”, accessed February 5, 2020, https://www.encyclopedia.com/environment/ encyclopedias-almanacs-transcripts-and-maps/music-religious-music-west.
} 
from the Psalms. Following the tradition of hymnody at Passover, it can be concluded that hymns sung in Judeo-Christian worship have scripture as their inspiration, theme, and lyrics. Hymns hence, are sacred and meant for the worship of God.

\section{Historical Development}

The congregational rendition of hymns from a dated period has been a popular characterization of hymnody. St Ambrose of Milan is recorded as instituting congregational hymnody but was minded as well, to counter the hymns of the Arians. As a pseudo-Christian cult, it seemed apparent, St. Ambrose's motivation to dissipate the falsehood and validation of cults through the adoption of Christian hymnody. The historical development of hymns is an indication of the critical role of hymnody which across different age periods could not be ignored but revived to catalyze movements and revivals. The strophic Latin hymn coming into being in the 4th century influenced hymnologists including St. Ambrose, Bishop of Milan, who were acquainted with and influenced by the hymns of the Eastern Churches. ${ }^{7}$

The restoration of congregational hymnody as a liturgical element during the Reformation was revitalized by the Lutheran Church in Germany. Before this time, however, German hymns were largely unharmonized and unaccompanied. Subsequently, the conflation of choral, congregation, and organ rendition emerged as a new phase of hymnody. Secular lyric patterns influenced the hymn texts of Luther and his contemporaries. The earliest of those collections were composed by Luther, Johann Walter (1524), and Georg Rhau (1544). ${ }^{8}$ The Counter-Reformation of the 16th century had inspired Roman Catholic hymns.

Pietism made its contribution to hymnody which diffused among the Lutherans and other groups including the Moravian Church in the $17^{\text {th }}$ and 18 th centuries. The late $17^{\text {th }}$ century marked a watershed in English hymnody beginning with the Independent Congregationalists hymnodist, John Watts. ${ }^{9}$ By the mid- $18^{\text {th }}$ century, under the Evangelical Revival, John and Charles Wesley, founders of Methodism finally mainstreamed hymnody in England and America. They borrowed much from German tunes with their later editions mimicking the style of Handel. ${ }^{10}$ Following a controversy arising from hymnody at Sheffield Church, England officially signed onto hymnody in 1820.

History has it that Charles Wesley began to write and sing hymns with his brother, John Wesley the preacher, in 1738 when they were filled with the Spirit. ${ }^{11}$ This would suggest that one is either filled with the Spirit to sing or must yield to the infilling of the Spirit, if not, to sing hymns unto God. Hymnal singing and spiritual awakening, revival is portrayed as sharing a relationship. Hence, hymns hold a key to refreshing in the body of Christ.

Later on, the Oxford Church, which was high-mass oriented encouraged three initiatives namely new compositions, translations from the Medieval Era as well as the use of plainsong melodies. ${ }^{12}$

Contemporary English hymnody traces back to Hymns Ancient and Modern, published in 1861 and revised in 2013 as Ancient and Modern: Hymns and Songs of Refreshing Worship. ${ }^{13}$ This hymnal at present stands as an integration with the Anglican Book of Common Prayer. In the $20^{\text {th }}$ century, the Yattendon Hymnal (1899) by Robert Bridges, and the English Hymnal (1906) were produced. Renewed interest in hymnody in the $19^{\text {th }}$ century led to the production of the West Minster Hymnal of 1940 in England. This period was followed by a re-introduction of congregational singing in England during mass in the 1960s, with the result of new hymns compositions and adoption of non-Roman Catholic source hymns. ${ }^{14}$

In Ghana, "choral music seems to have emerged from the colonial experience through a process of musical hybridity" 15 within the Methodist and Presbyterian mission in the nineteenth and early twentieth centuries. The musical forms at this epochal period utilizing both the European and indigenous musical

\footnotetext{
7 Encyclopedia.com, “Hymns And Hymnals, I: Historical Developments” accessed May 2, 2021, https://www.encyclopedia.com/ religion/encyclopedias-almanacs-transcripts-and-maps/hymns-and-hymnals-i-historical-developments.

8 Encyclopaedia Britannica, "Sacred Song" accessed April 7, 2021, https://www.britannica.com/topic/hymn.

9 Encyclopaedia Britannica, "Sacred Song."

${ }^{10}$ Encyclopaedia Britannica, "Sacred Song."

${ }^{11}$ Edward Dickenson, Music in the History of the Western Church (New York: Haskell House Publishers, 1969) 379-381.

12 Encyclopaedia Britannica, "Sacred Song."

${ }^{13}$ Marbecke's Book of Common Prayer with Notes, ed., Rimbault, (Novello, London) 1845.

${ }^{14}$ Prayer in Song, "A brief History of Armenian Liturgical Chant" accessed April 7, 2020, https://akn-chant.org/en/chant.

15 Stephen Tyle Spinner Terpening, "Choral Music, Hybridity, and Postcolonial Consciousness in Ghana" (PhD., University of Colorado School of Music, 2017),iii, https://scholar.colorado.edu/downloads/9c67wn09j
} 
features no doubt introduced classical hymnody that got assimilated through education in the school system.

"The Revival Movements of the Eighteenth and Nineteenth centuries brought a new dimension to hymns." 16 This historical fact implies that the dynamic of hymnody projects the practice as occupying a prime place in spiritual renewal movements. In 1904, the Ebenezer Baptist Church, after eleven o'clock on a Wednesday evening witnessed the beginning of a revival that was triggered by the ringing out of a solo voice with the hymn "Here is love vast as the ocean." This was an occurrence within the larger Welsh revival of which Evan Roberts was a chief instrument. ${ }^{17}$ Thus, the relationship of hymnody and character transformation that are the results of spiritual movements and revivals with the result of discipline and improved personality shared a coincidence.

\section{Significance}

Music is recognized as possessing the ability to engage the affections and unite mind and heart. In this, it focuses the mind upon one idea. This power of hymns gives it a particularly powerful pedagogical value in the church's ministry. Thereby, the instructional and more or less, the educative influence of hymnody is lucidly acknowledged. In its educative effect lies the power of hymnody to unite the heart and the soul. Porter ${ }^{18}$ has alluded to the potency of hymnody on the inner man, the soul, and the mind. Theologically the inner man is parallel to the rational aspect of man which refers to the id, ego, and super-ego analogy of the human personality. ${ }^{19}$ The analogy indicates the captivating power of hymnody to possibly shape behaviour to result in character transformation. Of the essence and role of hymnody in Christian spirituality, the observation has been made that hymns, in essence, construct a theology for every believer with a far-reaching impact on their soul. $^{20}$

The observation assumes the personalization of hymns by individual Christians. This means that for individual Christians, hymns are an encapsulation of their core doctrinal beliefs and theological statement. Observably, there are individual Christians with high preference and attachment to particular hymns, even though they maintain a general hymnody commitment.

Hymns have been reputed as expressing a sense of belonging to emphasize the common identity of the Christian calling and hope. These functional attributes of hymnody transform as variables of humanity and pride with the power to boost the psyche. These in turn inspire a sense of greatness, self-confidence, and worth. Such effects no doubt are emotive and psychological. Research has reported that choral singing helps to reduce stress, ${ }^{21}$ anxiety, ${ }^{22}$ depression, helplessness, and low self-esteem by boosting the immune system. ${ }^{23}$ Hymnody shares the effect of choral singing through mutual praxis. The psycho-social, physical and emotional responses evoked by singing, and invariably, hymnody have been engaged in a paper on choral singing and wellbeing. ${ }^{24}$

Hymnody's importance lies not only in the worship of God to fulfill a religious duty. It is also for the benefit of those who sing it as individuals and collectively as a faith community. Hymns are a source of inspiration, assurance, hope, strength, joy, peace, enlightenment, and reformation. For these invaluable benefits of therapeutic, edification, and spiritual value, the saints are advised to speak to one another with words of hymns among others, with a melody in their heart. Hymns must be sung with melody, both for selfregeneration and in praises to God. Its significance as a tool for the communion of the worshipper with God,

${ }_{16}$ Harry Eskew and Hugh McElrath, Sing With Understanding: An Introduction to Christian Hymnology accessed May 4, 2021, https://www.amazon.com/Sing-Understanding.

17 Brynmor Pierce Jones, An Instrument of Revival: The Complete Life of Evan Roberts 1878- 1951 (South Plainfield, NJ: Bridge Publishing, 1996).

18 Jacob Poters, "Songs of Suffering and Sanctification: The Hymnody of Anne Steele", The Southern Baptist Theological Seminary (2012). Accessed March 5, 2021 https://biblicalspirituality.files.wordpress.com/2010/03/.

19 Sigmund Freud. A General Introduction to Psychoanalysis. (New York: Washington Square Press, 1935).

20 A. Storr, Music and the Mind (New Yok: Free Press, 1992).

${ }_{21}$ David Aldridge, Music Therapy Research in Medicine and Practice: From out of Silence (London: Jessica Kingsley, 1996).

22 J.M.Winter, S. Parkin and T. Baker, "Music Reduces Stress and Anxiety of Patients in the Surgical Holding Area," Journal of Post Anesthesia Nursing, 9(6), (1994):340-343, accessed March 2, 2021, https://wwwaornjournal.online.wiley.com

${ }_{23}$ M., White. Music, "Therapy: An Intervention to Reduce Anxiety in the Myocardial Infraction Patient," Clinical Nurse Specialist, 6(2), (1992):58-63, 1992. https://www.pubmed.ncbi.nlm.nih.gov

24 E. O. Acquah. "Choral Singing and Wellbeing: Findings from a Survey of the Mixed-Chorus Experience from Music Students of the University of Education Winneba, Ghana” (December 16, 2026, p. 2 - 3). Accessed January 5, 2020. https:/ dxdoi/10.4314/ljh.v22712.1 
a channel for the blessings of the Spirit, edification, and the ecclesial communion of the Body of Jesus Christ is here emphasized. Thus, it provides a source of spirituality and is a key to mission and encounter.

\section{Utility and Form}

From the Methodist Hymn Book the statement, "a hymn is only a hymn if in it men speak to the most high and he to them." ${ }_{25}$ The statement emphasizes the critical place of hymns in man-and-God-interaction through dialogue or prayer. Thus, hymns find utility in prayer. Again, the utility of hymns finds relevance as a liturgical necessity. In Greek liturgical tradition, ${ }^{26}$ the features of hymnody are enumerated as follows: (1) Hymnody is an element of public or cathedral worship, (2) an element of daily services with priority to Sunday worship and feasts, (3) it is determined by liturgical books, and (4) rendered either by a choir or soloist. In congregational rendition, it is a two-part affair with a soloist doing the hymn and congregation taking the refrain.

Through hymnody, its agency either as heralding a homily or the reinforcer of the hymnal effect is much relied upon. Invoked as a necessary accompaniment of rites (sacraments) such as the Eucharist, baptism, matrimony, christening, requiems, the celebration of Christmas and Easter, including Mass, it fulfills its ritual utility.

Three prominent features identifiable to a lay mind are observable about hymns. The first is the metrical form they take. This form is about the measured manner in which hymns are arranged. The second identifiable feature is the manner of arrangement that is strophic or the stanzaic form. This arrangement presents hymns to be set in stanzas, giving them the appearance of poems with verses and a specific number of lines across its different verses. Thus, hymns by their manner of setting identify as a poetically arranged genre. Third, is the observable indirectly biblical lyrical content of persuasive import that frames them as songs of the Biblical faith.

\section{Interviews with Bookshop Keepers}

Currently, the title page of the Anglican Church hymnal reads, Anglican Church of Ghana: The Book of Common Prayer. At the Anglican Bookshop in Acca, the author was informed that the sale of the hymnal was encouraging but for the COVID 19 pandemic. The shopkeeper confirmed that the habit of carrying a hymnal to Mass sustains religiously with elite members of the Anglican Church.

The Catholic Hymnal was not on display at the bookshop of the Roman Catholic Church. Nonetheless, it was available for purchase. The Catholic hymnal combines English and Latin renditions even though it is majorly an English version with simple but neat formatting. It shares similar characteristics with the Book of Common Prayer, the hymnal of the Anglican Church that showed a tard appearance of all. So far, in Ghana, the Anglican hymnal is the only hymnal in a jacket. A psalter, special prayers, and rituals to be led either by a priest or deacon enfold in both Anglican and Roman Catholic hymnals.
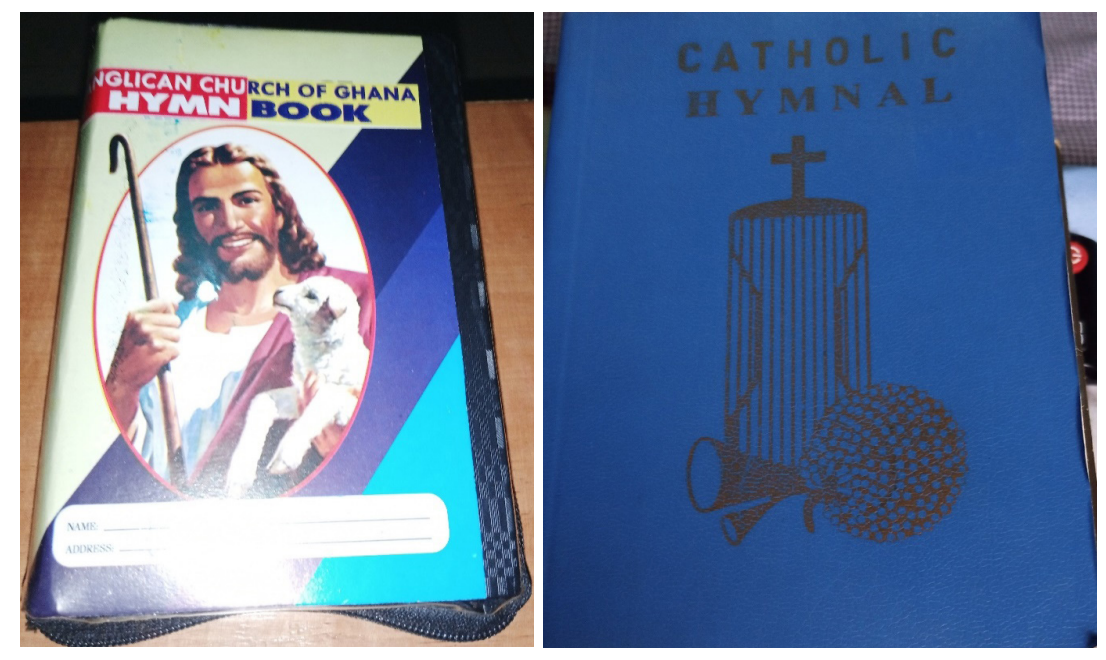

\footnotetext{
25 The Methodist Hymn Book Depot. Methodist Hymn Book, (Turkey, IMAK OFFSET. 2017).

26 Canterbury Dictionary of Hynology, "Greek Hymnody” by Stig Simeon Frøyshov, accessed November 22, 2020, https:// www.academia.edu/4874642/Greek_Hymnody
} 


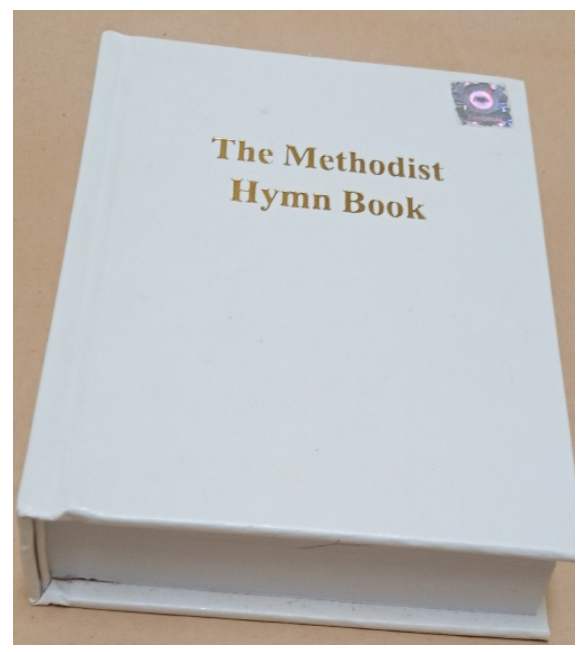

At the Methodist Bookshop in Accra, their hymnal which is in three versions namely the vernacular, English, and Master with tonic notation is on sale. The Methodist and Presbyterian hymnals prefer rich historical narratives as inclusive frontal matter. The features include a simple introduction and the usual printer reference page as frontal matter. According to the shopkeeper, their hymnals had good patronage that has plummeted due to the COVID 19 pandemic.

The Presbyterian Bookshop also confirmed an all-year-round encouraging hymnal sale. Their hymnal comes in two versions of Assre Dwom Nhoma, the vernacular, and the Presbyterian Hymn Book, which is in English. The Presbyterian and Methodist hymnals display richly designed covers and formatted make.
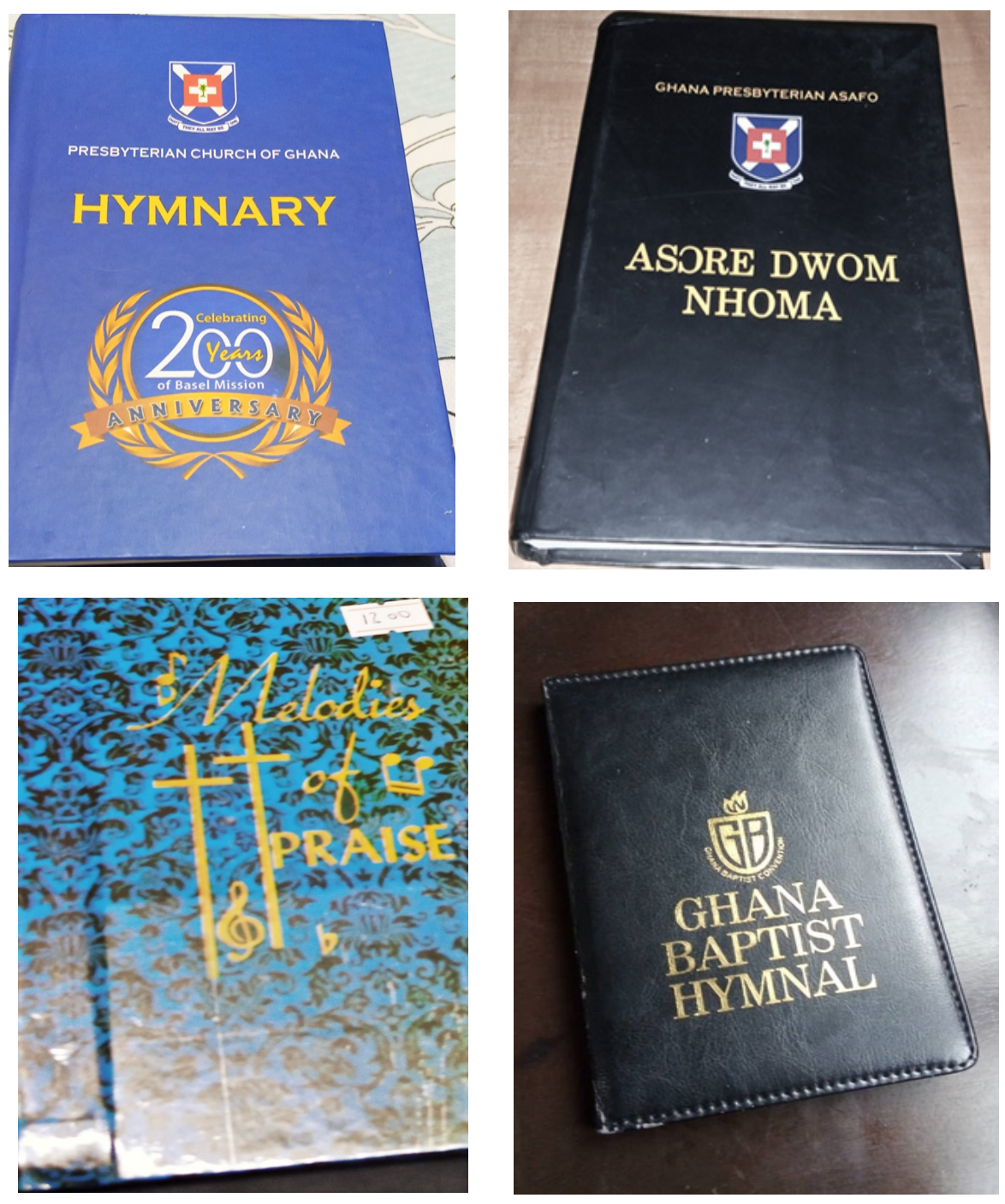
The Assemblies of God Church (AoG) boasts of an English hymnal, the Melodies of Praise which has simple but neat formatting. It is of two designs namely the soft-bound and hard-bound giving personal preference options for buyers. At AoG Bookshop, the author was informed that the patronage of Melodies of Praise is an all-year-round activity. Hymnody is a liturgical element of this church which is normally done after congregational prayer in the preliminary part of the service and as a closing activity. The carrying of the hymnal to church is customary in AoG. As an ongoing phenomenon in AoG, screen projection of hymns seems to be catching up with their metropolitan churches.

The Baptist hymnal has a rich black leather cover and neat formatting. As confirmed by the bookshop keepers, special occasions such as anniversary celebrations, weddings, and requiems trigger higher sales of hymnaries. Bulk purchases by hosts for their guests in gratitude and as souvenirs, explain the high hymnal sales on special occasions. According to the bookshop keepers, the supply of their hymnals to the institutions of learning adds to the overall yearly sales. The Anglican, Roman Catholic, Methodist, and Presbyterian Churches are at the forefront of this drive due obviously to their ownership and missioning responsibilities over institutions of learning. The Methodist and Presbyterian hymnals were observably highly stocked in their bookshops, with AoG and Baptist hymnals indicating visible presence on the shelves in their bookshops. Prices of hymnals ranged between twelve and twenty-two Cedis at the time of the investigation.

\section{ANALYSES}

Common to all the hymnals are the usual table of content and index for user-friendly utility. These are differently positioned, however, either in the frontal or end matter portions. Remarkable of the design of the hymnals are a sense of aesthetics but also reasonable pricing to ensure affordability and durability. Largely, the notions of respectability, identity, and pride imbue the designs to denote hymnals as symbolic items. Compact and normal book size diameters are characteristic features. Two reasons plausibly explain hymnal sizes, the first of which is accommodation for full content and inner matter of a hymnal. The Presbyterian and Methodist hymnals, for example, contain close to one thousand hymns and so the compact size serves as a containment strategy. Secondly, standard or bold font characters as found in the Anglican, Baptist, and Catholic hymnals compensate, obviously, for volume inadequacy or maximization to achieve design and formatting objectives.

\section{FINDINGS OF SURVEY AND ANALYSES}

The research question was:

What is your best comment on the hymnody of devoted church members?

\begin{tabular}{|l|c|c|}
\cline { 2 - 3 } \multicolumn{1}{l|}{} & PERCENTAGE SCORE & INFORMANTS \\
\hline $\begin{array}{l}\text { a. } \text { A religious melody } \text { Has the power to transform character and shape } \\
\text { personality. }\end{array}$ & $26 \%$ & 78 \\
\hline c. They are short sermons with conviction & $41 \%$ & 123 \\
\hline d. An activity for a literate church & & 60 \\
\hline e. Other & $20 \%$ & 9 \\
\hline Total & $3 \%$ & 30 \\
\hline
\end{tabular}

Survey Findings in a Table

Out of 78 informants of a total of 300 representing $26 \%$ of the respondent population whose best understanding of hymnody is that it is a religious melody, they projected the perspective of musical classification. Thus, there was the inference to a musical genre but with exclusive utility by a specific social segment i.e., the church community and hence, religion. By their understanding, they viewed hymnody as a religious practice which was the emphasis that hymnody is an integral religious accompaniment and perhaps, another in the variety of religious music. The implication is that some observe hymnody as not necessarily of salvific, pedagogical, and transformative significance but something of mere ritual significance, and perhaps, of no consequence. It would seem that such persons, though, may observe and partake in hymnody, do so without attachment and devotion. 
Out of 123 informants, a total of 300 representing $41 \%$ who see hymnody as powerful to transform character and shape personality, they speak from an emic standpoint and with a perspective of personality development and character transformation. Thus, they do not analyze hymnody as a mere practice but something that benefits its devoted participants by growing them into maturity. Inferring the maturity of the in-ward man, the notions of pedagogy and discipline are underscored as transforming outcomes of devoted hymnody participation.

Considered as a short sermon with conviction, 60 informants of a total of 300 , representing $20 \%$ of the respondent population who were thus persuaded about hymnody, indicated the persuasiveness of hymnody, which attests to its power on the soul. Thus, content and end-result analyses to indicate effect perspectives of hymnody were here deduced by the respondents, with the conclusion that hymns are impactful.

Those who indicated that hymnody is an activity for church literate were 9 informants representing $3 \%$ of the total survey population 300 . Their view is a suggestion that illiteracy is a barrier to hymnody. By implication, they suggested that ways must be found to remove the illiteracy barrier to hymnody.

Of those asserting views other than the four options in the questionnaire were 30 informants representing $10 \%$ of the total survey population of 300 . Out of this number, 9 informants said that hymns were Western and un-African. The assertion suggested racial sentimentality, indigeneity, and language barrier to hymnody. Thus, an Afrocentric perspective informs the analysis of hymnody in the Ghanaian church. Out of that 30 informants again, of a total survey population of 300 , they felt that hymns were a high-class activity intended to satisfy that class and thus, impute elitism to the practice of hymnody. Also, out of the same 30 respondents of the survey population of 300, 15 informants insisted on congregation-participation hymnody other than an audience-targeted activity or only choir hymnody performance. This is a suggestion that in some churches in Ghana, hymnody is an exclusive activity where the congregation sits as an audience and is at the receiving end of the performance. The observation exposes the tension between church culture and the biblical instruction for all the saints to sing hymns.

\section{RECOMMENDATIONS}

Based on the analysis of the response that hymnody is an integral religious accompaniment in liturgy, the church must work towards improving the perception and understanding of hymnody, its significance, role in worship as well as its outcome on the worshipper. This effort should hinge on a background of regeneration, penitence, and docility to the word of God. Participation in hymnody among believers should be encouraged, but again, from a background of a regenerated experience.

As a tool for inner growth and maturity, the participation, sustenance, and replication of hymnody ought to be encouraged. In that direction, it should be observed as a regular liturgical Mass or church service activity.

Due to the transforming nature of hymnody and its power to shape personality, the reading of hymns as a way to draw attention to its content and meaning is to be seriously considered. Thus, the stimulation to ponder and reflect hymnody for maximal impact on its participants should forever remain a focus of the church.

Due to the perception that hymnody in Ghana is elitist and bars the non-literate from its participation, methodologies ought to be devised including the reduction of classical hymns into vernacular and the use of rote method learning to overcome the barrier to hymnody among the non-literate. Furthermore, vernacular hymnody is to be encouraged in churches where Western hymns dominate.

The Afrocentric view of hymnody demands inculturation ${ }^{27}$ of classical hymnody with emphasis on home-grown vernacular hymns as pertains in some churches including the Methodist, Presbyterian, and Evangelical Presbyterian.

\section{CONCLUSION}

The findings of the investigation have given evidence that devoted participation in hymnody yields a beneficial outcome. With $41 \%$ of informants indicating that hymns are transformative and $20 \%$ saying that hymns are little sermons with conviction, it gives support to the transforming power of hymns on character transformation and personality shaping with correlation to discipline. The evidence is an emphasis on the impact of hymnody

\footnotetext{
27 The adaptation of Christian liturgy or its elements to a non-Chriatian cultural background.
} 
as rewarding and beneficial to mood and character change to stimulate the transformation of soul and mind, leading to the growth of the inner man as a function discipline.

In a church service, there is a mix of songs intended to satisfy all the demographics. To register qualms about something that morally and legitimately satisfies a group in the church i.e., the elite, is to create the impression that the rest are ignored. This posture is not a reflection of the spirit of togetherness which implies unity in diversity. It is said in the Bible that "and all that believed were together, and had all things common ... and they, continuing together daily one with accord in the temple" (Acts 2: 44-46). Diversity of taste should impress a sense of accommodation even for something that is not in sync with individual taste, in the recognition of diversity and respect for the satisfaction of others in society, as a mark of personal transformation and discipline.

\section{ABOUT AUTHOR}

Edwin Boateng Afriyie is an ordained minister of God since 1988 and is the pioneer of Heritage Interdenominational Baptist Church in Oyibi - Accra. Presently, he lectures in the Department of Theology at Christ Apostolic University College, Kumasi. In the past, he was Dean of Students' Affairs and Lecturer at Maranatha University College, Accra. He is a Ph.D. candidate at the Institute of African Studies, University of Ghana. His research interest is in Religion in the public space.

\section{BIBLIOGRAPHY}

Acquah, E. O., "Choral Singing and Wellbeing: Findings from a Survey of the Mixed-Chorus Experience from Music Students of the University of Education Winneba, Ghana" (2016) 2 - 3. https://dxdoi/10.4314/ljh.v22712.1

Aldridge, David. Music Therapy Research in Medicine and Practice: From out of Silence., London: Jessica Kingsley, 1996.

Britannica "Hymn." Accessed April 28, 2020. http://www.britannica.com/topic/hymn

Catholic Book Centre. Catholic Hymnal. Accra: Buck Press, 2015.

Canterbury Dictionary of Hymnology, "Greek Hymnody” by Stig Simeon Frøyshov. Accessed November 22, 2020, https://www.academia.edu/4874642/Greek_Hymnody.

Britannica "Kontakion: Byzantine poetic form." Accessed July 19, 2020. https://www.britannica.com Dickenson, Edward. Music in the History of the Western Church. New York: Haskell House Publishers, 1969.

Encyclopedia.com “Hymns And Hymnals, I: Historical Developments.” Accessed May 2, 2021. https://www.encyclopedia.com/religion/encyclopedias-almanacs-transcripts-and-maps/hymns-andhymnals-i-historical-developments

Eskew, Harry, and McEltath, T. Hugh "Sing With Understanding: An Introduction to Christian Hymnology”, (1980), 91. https://www.amazon.com/Sing-Understanding.

Freud, Sigmund. A General Introduction to Psychoanalysis. New York: Washington Square Press, 1935. Graham, Deans. "Hymnody and Belonging" Summer \& Autumn Bulletins, 220 \& 221. Accessed October 18, 2020. https://hymnsocietygbi.org.uk/1999/07/treasure-no-65-hymnody-and-belonging/

Marbecke's Book of Common Prayer with Notes, ed., Rimbault. London: Novello, 1845.

Poters, Jacob. "Songs of Suffering and Sanctification: The Hymnody of Anne Steele", The Southern Baptist Theological Seminary (2012). https://biblicalspirituality.files.wordpress.com/2010/03/songs-ofsuffering-and-sanctification-the-hymnody-of-anne-steele-by-jake-porter.pdf

Richard, G. Tedeschi, and Calhoun, G., Lawrence. (2012). Pathways to Personal Transformation: Theoretical and empirical developments, In P. T. P. Wong (Ed.), Personality and clinical psychology series. The Human quest for meaning: Theories, research, and applications (p. 559-572). Routledge/Taylor \& Francis Group. Accessed July 17, 2020. https://psycnet.apa.org.re...

Jenkins, Roy. "The Welsh Revival” accessed May 4, 2021, https://www.bbc.co.uk/religion/religions/ christianity/history/welshrevival_1.shtml\#top

Storr, Anthony. Music and the Mind. (New York: Free Press), 1992. 
Terpening, Stephen Tyle Spinner. "Choral Music, Hybridity, and Postcolonial Consciousness in Ghana." PhD., University of Colorado School of Music, 2017.

https://scholar.colorado.edu/downloads/9c67wn09j · PDF file.

The Methodist Hymn Book Depot. Methodist Hymn Book. Turkey, IMAK OFFSET. 2017.

White, J. Music Therapy: An Invention to Reduce Anxiety in the Myocardial Infraction Patient. Clinical Nurse Specialist, 9 (6), 34-343,1994).

Winter, J. M., Parkin, S., \& Baker, T. "Music Reduces Stress and Anxiety of Patients in the

Surgical Holding Area." Journal of Post Anesthesia Nursing, 996), 340-343, 1994. Accessed November 25, 2020. https://wwwaornjournal.online.wiley.com 